\title{
MULTIPLE PULMONARY ARTERY ANEURYSMS
}

\author{
BY \\ ROBERT W. CHARLTON AND LOUIS A. DU PLESSIS \\ From the Departments of Medicine and Thoracic Surgery, University of the Witwatersrand, \\ Johannesburg
}

(RECEIVED FOR PUBLICATION MARCH 21, 1961)

Aneurysms of the larger pulmonary arteries are rare. Up to 1946 Deterling and Clagett (1947) had collected 147 cases of aneurysms of the trunk and right and left main branches, including the 111 cases previously reviewed by Boyd and McGavack (1939). Several further examples have since been reported (Dotter and Steinberg, 1949 ; Priviteri and Gay, 1950 ; Clifford, MacGillivray, and Goodale, 1950 ; Blades, Ford, and Clark, 1950 ; Lindert and Correll, 1950 ; Grelland, 1950 ; Israels, 1951 ; Zaky, 1952 ; Franklin and Ritchie, 1956 ; Jelinek and Owen, 1958 ; Contro, Miller, White, and Potts, 1958 ; Reid and Stevenson, 1959 ; Smith, 1959). Aneurysms of the secondary and tertiary branches appear to be even more uncommon than those of the trunk and primary branches, since the available literature has yielded only 30 cases. The wellknown Rasmussen's aneurysms related to tuberculous cavities, and the occasional report of mycotic aneurysm formation following direct extension of infection from a septic focus in the lung, have been excluded. It is the purpose of this paper to report a further case of multiple mycotic aneurysms of the large intrapulmonary arteries, and to review briefly the available literature. A short discussion of the pathogenesis of aneurysms of these vessels is included.

\section{CASE Report}

A white male clerk aged 25 years was admitted on November 1, 1959, complaining of fever with occasional rigors, and pains in the back, chest, and limbs for the last six weeks. Various joints in turn had been painful and swollen. He had had no cough or sore throat. $\mathrm{He}$ had previously been well apart from recurrent boils since adolescence. On examination he was pyrexial $\left(101.8^{\circ} \mathrm{F}\right.$.) and there was a tachycardia (104/minute). There was a small abscess of the scrotum, and the right knee and ankle joints were swollen, hot, and tender. No other abnormality was detected. The haemoglobin was $13.5 \mathrm{~g} . \%$ and the leucocyte count $7,700 /$ c.mm. with $62 \%$ neutrophils. The E.S.R. was $42 \mathrm{~mm}$. in one hour (Wintrobe). Total serum proteins were $7.4 \mathrm{~g} . \%$, of which $\gamma$ globulin formed $2.54 \mathrm{~g} . \%$. C-reactive protein was present
$(+++)$. The streptococcal antihaemolysin 0 titreo was 250 units $/ \mathrm{ml}$. The typhoid and brucella $a^{+}$ agglutination reactions and the rickettsial and vira $\mathrm{B}$ complement-fixation tests were negative. Blood cultures were negative on two occasions. The electrocardiogram and radiographs of the chest and right ankle were normal.

A diagnosis of rheumatic fever was suspected, and 15 grains of aspirin together with 500,000 units of penicillin intramuscularly were given six-hourly. How-e ever, a remittent pyrexia with occasional rigors? persisted over the next two weeks, and although the arthritis had subsided the chest and muscular painso continued and the scrotal abscess was larger. In spite of the negative blood cultures a diagnosis of septicaemia now seemed likely, and treatment with $250 \mathrm{mg}$. oral chlortetracycline six-hourly and $\frac{1}{2} \mathrm{~g} \mathbb{\mathscr { Q }}$ streptomycin intramuscularly twice daily was started Further investigations had been performed during the second week. Six more blood cultures were negative. The haemoglobin was $14 \mathrm{~g} . \%$, the leucocytes $14,100 /$ c.mm. with $63 \%$ neutrophils, the E.S.R. was $40 \mathrm{~mm}$. in one hour (Wintrobe), and C-reactive protein was still present $(+++)$. No L.E. cells were seen in을 suitable preparations, and the agglutination tests $\underset{\times}{\times}$ were still negative. A second radiograph of the chesto (Fig. 1) on November 20,19 days after admission, 3 . showed a triangular opacity in the periphery of the posterior segment of the right upper lobe, with an 3 associated pleural reaction, and obscuring of the right costophrenic angle by pleural reaction. The appear- -5 ance was considered to be compatible with septic pulmonary infarction, the source of the emboli being presumably the pelvic veins. The patient still had N no cough.

Four weeks after admission, on November $27,1959, N$ the pyrexia continued. Staphylococcus aureus N్ sensitive only to erythromycin had been cultured from ${ }_{\sigma}$ the scrotal abscess and also from a nasal swab. Two further blood cultures were negative. The opacity in the right upper lobe persisted. Erythromycin was $\mathbb{\Phi}$ given orally in doses of $500 \mathrm{mg}$. six-hourly. The ? patient's condition improved dramatically from this time, and a week later, on December 3, 1959, the $\stackrel{\circ}{\circ}$ temperature was normal. The scrotal abscess had $\stackrel{\mathbb{D}}{\mathbb{D}}$ healed, the pains had disappeared, and he felt well. $\mathbb{\Phi}$ Erythromycin in the same dose was continued for a further 19 days, during which time he remained 


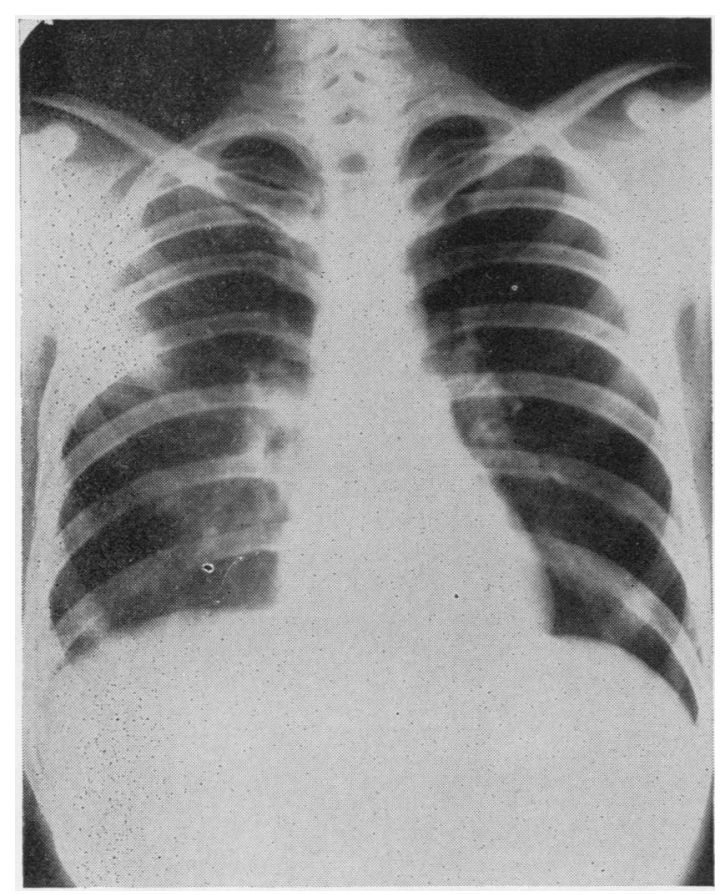

FIG. 1.-Postero-anterior chest radiograph on November 20, 1959, showing a triangular opacity in the right midzone with an associated pleural reaction. In addition the right costophrenic angle is obscured by a pleural reaction.

apyrexial and asymptomatic. $\mathbf{A}$ radiograph of the chest just before his discharge on December 22, 1959, showed that the opacity in the right upper lobe was still visible although much less distinct. When seen at the follow-up clinic a month later he was well. Although proof in the form of a positive blood culture had not been obtained, it was thought that his illness had been a staphylococcal septicaemia.

He failed to return to the out-patient clinic even though in March, 1960, he again began to experience rigors. During an attack he would cough up a small amount of blood. At first the attacks recurred about once a fortnight, but then became more frequent. He felt run-down and tired, and had several boils. He did not consult a doctor for fear of being put off work again, but during April he obtained a supply of erythromycin and dosed himself with it for four days, with possibly some improvement in his symptoms.

In May the rigors and haemoptyses were occurring almost daily, and towards the end of May he had a massive haemoptysis: he was then seen at another hospital where he was admitted. Shortly after admission he had a second major haemoptysis, and he was transferred to the Thoracic Surgical Unit of the Johannesburg Hospital for further investigation.

On examination on June 8, 1960, there was slight clubbing of the fingers, but no pallor or cyanosis.
The temperature was $99.4^{\circ} \mathrm{F}$. No abnormality was detected on clinical examination. The haemoglobin was $13.3 \mathrm{~g} . \%$ and the leucocyte count was 11,600 with $73 \%$ neutrophils. No L.E. cells were seen in suitable preparations. C-reactive protein was present $(+++)$. A chest radiograph on June 9 (Fig. 2) showed a spherical soft-tissue density in the right lower zone with apparent enlargement of the right hilar glands. The triangular opacity in the right upper lobe visible during the first admission was no longer seen.

Tomography (Figs. 3 and 4) showed several rounded shadows related to the right hilum, although the bronchi appeared normal.

A bronchoscopy under general anaesthesia revealed no abnormality and a bronchogram was normal. A low-grade pyrexia persisted, and on June 27, 1960, he had a further large haemoptysis. Radiographs now showed an increase in size of the right lower opacity and greater prominence of the right hilum.

On July 1, 1960, right lateral thoracotomy was performed with the intention of obtaining a biopsy specimen. Pleural adhesions made it impossible to explore the hilum through the incision, but palpation of the lung failed to reveal any masses corresponding to the radiographic opacities. A biopsy was taken from the lateral segment of the right lower lobe, and sections of this material showed a resolving infarct.

On July 10 he had a sudden massive haemoptysis. He became extremely distressed and was immediately taken to the theatre. On arrival he was unconscious, so a bronchoscope was introduced and the blood was aspirated as fast as possible. The haemorrhage was so profuse that it was impossible to determine the

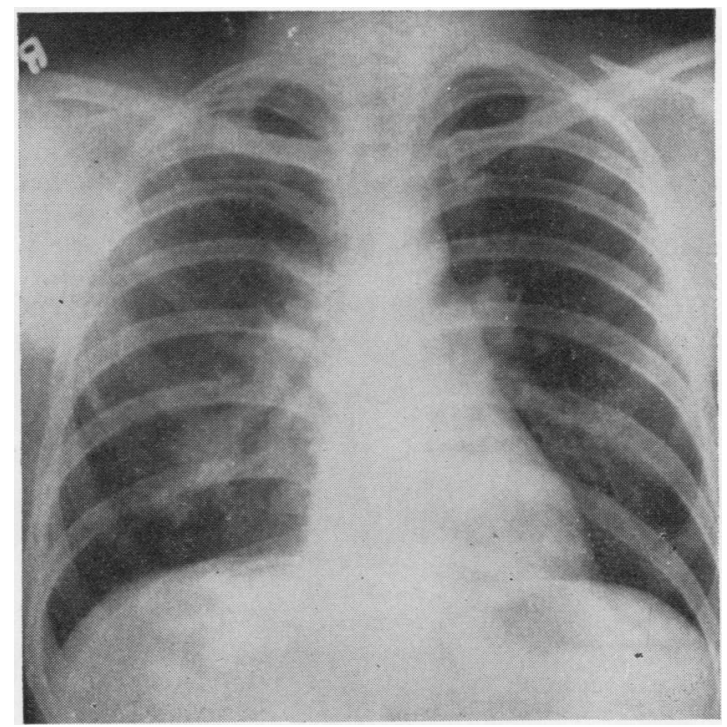

Fig. 2.-Postero-anterior chest radiograph on June 9, 1960, showing a rounded opacity in the right lower zone with enlargement of the right hilar shadow. The triangular opacity in the right midzone is no longer seen, and the costophrenic angle appears normal. 


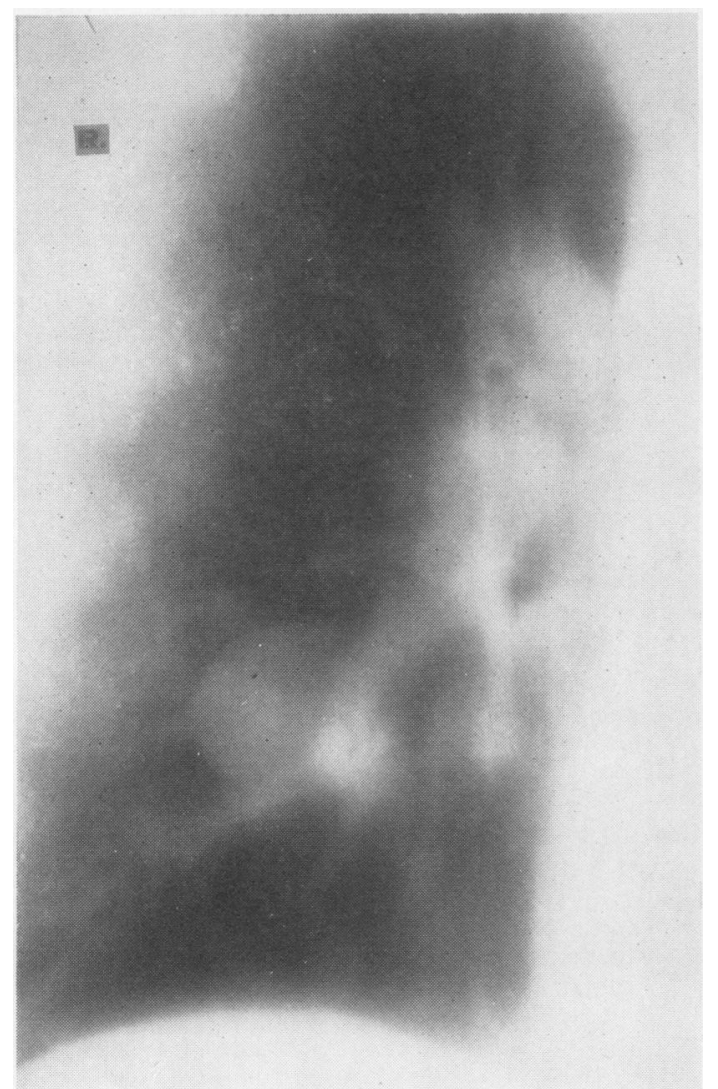

FIG. 3

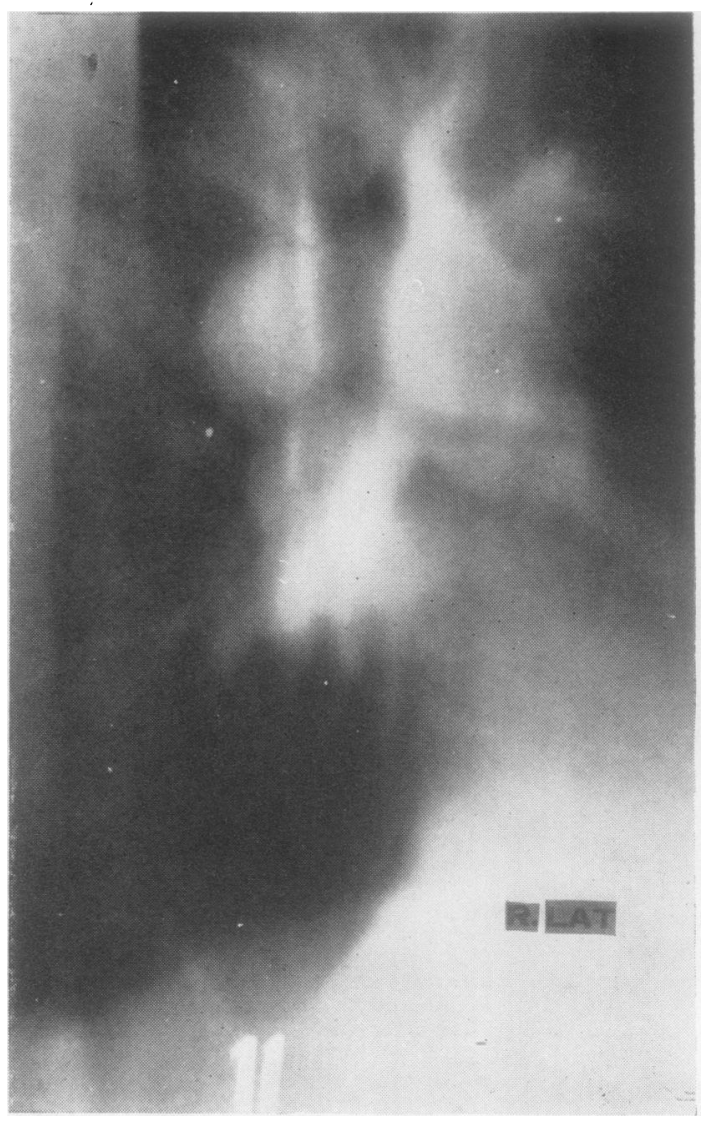

Fig. 4

FIGs. 3 and 4.-Postero-anterior and lateral tomograms of the right hilar region showing; several rounded shadows. The bronchi appear normal.

site of origin of the bleeding. The heart then stopped beating, though after 10 minutes of cardiac massage normal contractions returned. As it could be seen through the thoracotomy incision that the bleeding point was in the left upper lobe, the pulmonary artery to this lobe was ligated. After this no further haemorrhage occurred, but in spite of transfusion the patient died one and a half hours later.

\section{NECROPSY REPORT}

Dr. M. D. E. Manson performed the necropsy.

The mouth, larynx, and trachea contained fresh blood, and both lungs were filled with blood. The hilar lymph nodes were moderately enlarged, pigmented, and soft. There were multiple aneurysms of the secondary and tertiary branches of both pulmonary arteries varying in size from $2 \mathrm{~mm}$. to $5 \mathrm{~cm}$.

The heart was enlarged (420 g.) and the enlargement was confined to the right ventricle which was both dilated and hypertrophied. The pulmonary valve was competent and normal. The tricuspid valve showed a slight relative incompetence. There was an area of thickened, opaque endocardium, $\frac{1}{2} \mathrm{~cm}$. in diameter, on one of the papillary muscles of the tricuspid valve with a small, adherent, antemortem thrombus. There was no other cardiac abnormality.

Apart from moderate enlargement of the spleen (340 g.), no significant pathological lesion was identified in any other organ.

Sections of the lungs showed blood in the alveoli with patchy interstitial fibrosis. The pulmonary aneurysms showed scarring of the walls with destruction of the elastic laminae and muscle, and fibrosis (Fig. 5). Fibrosis was particularly marked in the adventitia and extended into the adjacent tissues. The intima showed marked proliferation and recent organized antemortem thrombus was present in most of the aneurysms examined. In some of the aneurysms the features of active subacute inflammation were observed with a dense infiltration of nongranular inflammatory cells, including numerous plasma cells. These features were consistent with the appearances of healing mycotic aneurysms.

The hilar lymph nodes showed a very severe active subacute lymphadenitis; there was marked sinus 


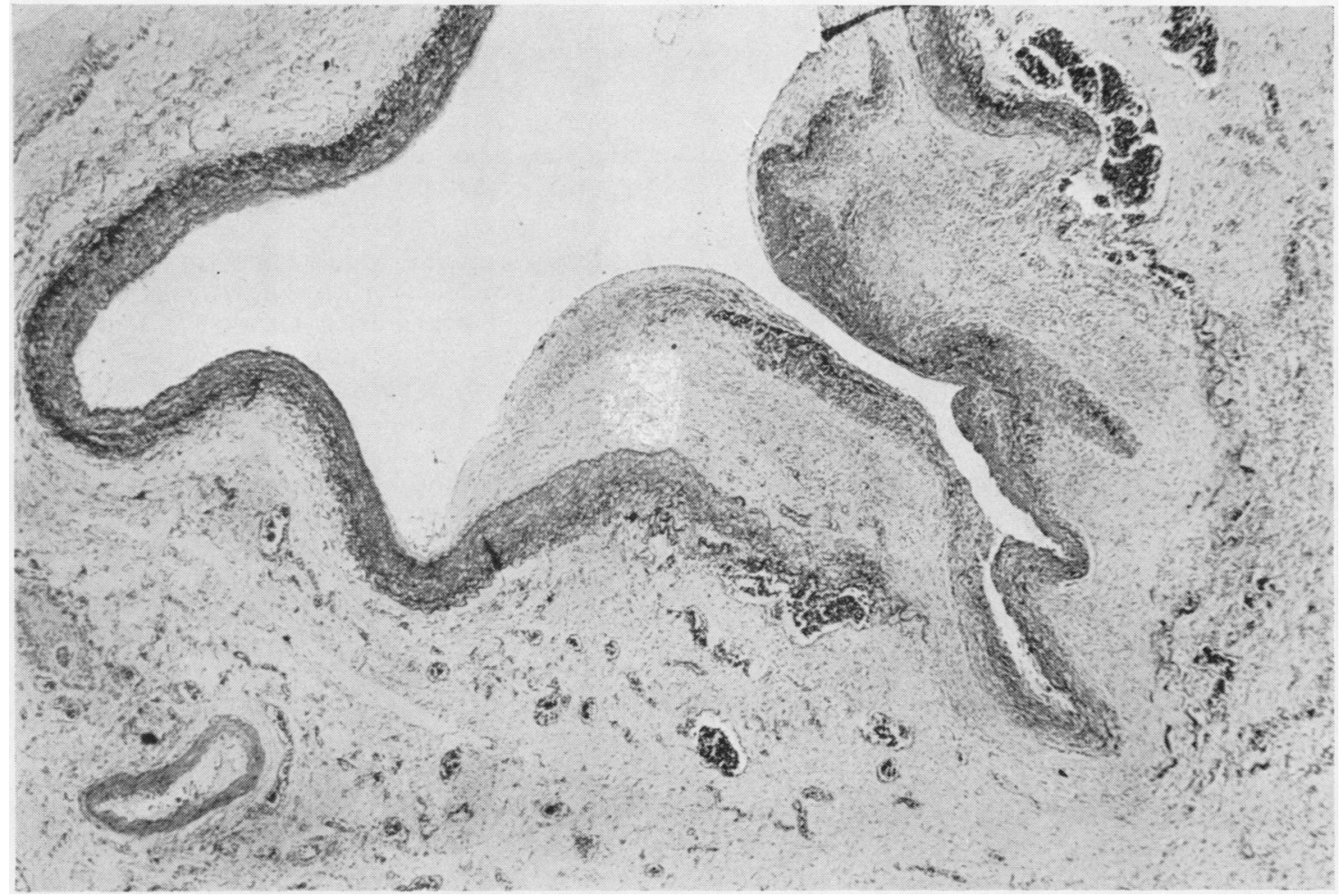

Fig. 5.-Low-power view of a small pulmonary artery showing aneurysm formation, with destruction of the elastic laminae, and fibrosis extending into the surrounding tissue. There is organized antemortem thrombus in the aneurysm ( $\times 30$ elastic Masson).

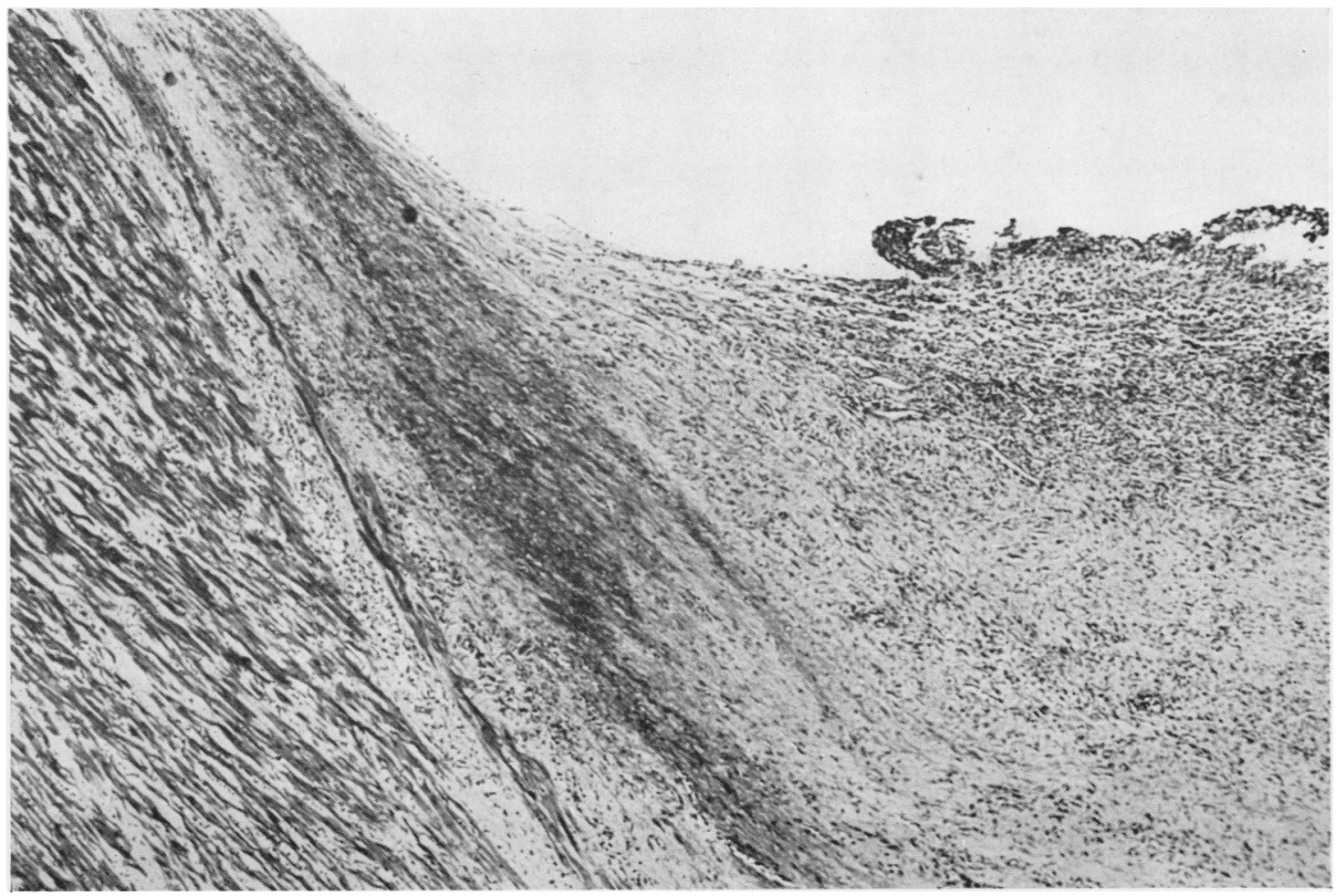

FIG. 6.-Section of a papillary muscle of the tricuspid valve showing organizing antemortem thrombus ( $\times 45$ elastic Masson). 
catarrh and an infiltration of plasma cells, eosinophils, and occasional neutrophils.

Sections of the papillary muscle of the tricuspid valve showed the features of an organized endocarditis (Fig. 6). In the thrombus a few Gram-positive cocci were identified. There was no evidence of rheumatic heart disease.

Sections of the spleen showed numerous plasma cells and polymorphonuclear leucocytes in the red pulp.

\section{Discussion}

In view of the necropsy findings we think it likely that the illness which occasioned the first hospital admission was a septicaemia, probably staphylococcal. The remittent fever, the scrotal abscess, the absence of evidence for an alternative diagnosis and the apparent response to erythromycin (the only antibiotic to which the staphylococcus cultured from the scrotal abscess was sensitive), had led to this clinical diagnosis at that time. Hay (1960) has stated that septic infarction of the lungs is common in staphylococcal septicaemia. The lesions give rise to discrete circular or triangular opacities on chest radiographs, similar to the appearances seen in the present case (Fig. 1). The absence of cough is apparently not unusual.

The failure to obtain positive blood cultures in spite of repeated attempts may be explained by the absence, apart from some enlargement of the spleen, of evidence of infection of the systemic circulation at necropsy. Blumgart (1933) and Barker (1949) reported the relative infrequency of positive blood cultures in cases of right-sided endocarditis, although Bain, Edwards, Scheifley, and Geraci (1958) found positive cultures in 17 of 18 cases seen at the Mayo Clinic. It is not clear why the filtering action of the lung, observed experimentally by Wright (1927), should be so efficient in these cases and yet apparently nonexistent in cases of generalized septicaemia or pyaemia. The bypassing of the lung capillaries through the right-to-left shunt by bacteria is considered to be one at least of the factors responsible for the development of brain abscesses in cyanotic congenital heart disease (Newton, 1956 ; Campbell, 1957). Campbell (1957), however, doubts whether individual bacteria are held up in the lung capillaries, and suggests that the filtering effect is due to the removal of larger particles, such as clumps of bacteria or infected emboli. Possibly the antibiotic treatment in our patient suppressed the multiplication of the cocci in the blood-stream, but was not sufficient to eradicate those organisms which were embedded in clot; the condition was thus one of septic embolization rather than septicaemia. The emboli presumably came from pelvic veins, but unfortunately these were not examined at necropsy.

Bain et al. (1958) have stated that only 5-10\% of cases of bacterial endocarditis are right-sided. The lesser incidence of rheumatic valvular damage and the lower pressures on the right account for the infrequency of subacute infection, and hence for the greater proportion of acute to subacute endocarditis. Rigors and pulmonary symptoms are common presenting features. Murmurs are heard in only about half the cases and the spleen is felt in about $25 \%$. Chest radiographs show shadows which are usually interpreted as pulmonary infiltration or pneumonitis. The staphylococcus is the most commonly encountered organism, and the tricuspid valve is involved more frequently than the pulmonary.

The recurrence of symptoms in our patient could have been due either to failure to eradicate the infection during the first admission, or to a new infection of the blood-stream from a fresh septic focus. Although the course of erythromycin was continued for 19 days after the temperature had returned to normal, the organism is notoriously resistant, and Fisher, Wagner, and Ross (1955) recommend that treatment should be continued for six to seven weeks. Possibly, however, a new infection of the blood occurred, as the patient had had further boils before the onset of symptoms of the second illness. Tulloch, Alder, and Gillespie (1960) have obtained good results in the treatment of recurrent furunculosis by attacking the carrier site, and as a staphylococcus had been cultured from the patient's nose local treatment of this area would have been worth while.

A mycotic aneurysm may form when an organism reaches the media of the artery by direct extension from a neighbouring focus of infection, from the blood-stream via the vasa vasorum, or by invasion of the intima from the lumen after the lodgment of a septic embolus. The vasa vasorum of the pulmonary vessels arise from the bronchial arteries, i.e., from the systemic circulation (Verloop, 1948), and in view of the scanty evidence at necropsy of infection in the systemic circulation in our case it seems unlikely that this mechanism was responsible. There were no abscesses in the lung parenchyma from which infection might have spread to involve the vessel wall from the outside, and it seems likely that direct invasion of the intima from the lumen occurred. The attacks of shivering with chest pain and haemoptysis before 
TABLE

SUMMARY OF THE LITERATURE

\begin{tabular}{|c|c|c|c|c|c|}
\hline Case & Authors & Age & Associated Findings & Aetiology & Remarks \\
\hline 1 & $\begin{array}{l}\text { Fern (1848) quoted by Barnes } \\
\text { and Stedem (1933) }\end{array}$ & $?$ & & ? Congenital & Died of massive haemoptysis \\
\hline 2 & Thompson (1877) $\ldots$ & 20 & $\begin{array}{l}\text { V.S.D. + subacute bacterial } \\
\text { endocarditis }\end{array}$ & Mycotic & $\begin{array}{l}\text { Also an aneurysm of the middle cerebral, } \\
\text { probably mycotic }\end{array}$ \\
\hline 3 & $\begin{array}{l}\text { Sachs (1892) quoted by } \\
\text { d'Aunoy and von Haam } \\
\text { (1934) }\end{array}$ & 21 & $\begin{array}{l}\text { Patent ductus + subacute } \\
\text { bacterial endocarditis }\end{array}$ & , & \\
\hline 4 & $\begin{array}{l}\text { Kidd (1893) quoted by Deter- } \\
\text { ling and Clagett (1947) }\end{array}$ & 22 & , $\quad$,,$\quad$, & , & \\
\hline 5 & $\begin{array}{lll}\text { Churton (1897) } & \ldots\end{array}$ & 12 & Tricuspid endocarditis & , & $\begin{array}{l}\text { Accentuated } P_{2} ; \text { no mention of underlying } \\
\text { congenital or rheumatic disease }\end{array}$ \\
\hline 6 & $\begin{array}{lll}\text { Krzyszkowski (1902) } & \ldots \\
\text { Humphry (1912) } & \ldots & \ldots\end{array}$ & $\begin{array}{l}17 \\
18\end{array}$ & $\begin{array}{l}\text { Patent ductus +S.B.E. } \\
\text { A.S.D. + high V.S.D. } \\
\text { S.B.E. }\end{array}$ & 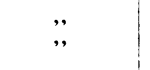 & Died of massive haemoptysis \\
\hline 8 & Trevor (1912) $\quad \ldots \quad \ldots$ & 24 & $\begin{array}{l}\text { Pulmonary and aortic endo- } \\
\text { carditis }\end{array}$ & , , & $\begin{array}{l}\text { Accentuated } \mathrm{P}_{2} \text {; no mention of underlying } \\
\text { congenital or rheumatic disease }\end{array}$ \\
\hline 9 & Beattie and Hall (1912) $\quad$. & 21 & Vegetation in $\mathbf{R}$. ventricle & 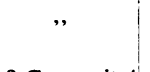 & $\begin{array}{l}\text { Attacks of chest pain and shivering with } \\
\text { haemoptysis following thrombophlebitis } \\
\text { of leg. Died of a massive haemoptysis }\end{array}$ \\
\hline 10 & $\begin{array}{l}\text { Wilkens (1917) quoted by } \\
\text { Barnes and Stedem (1933) }\end{array}$ & $?$ & 一 & ? Congenital & \\
\hline $\begin{array}{l}11 \\
12\end{array}$ & $\begin{array}{l}\text { Warthin (1917) } \\
\text { Konjetzny (1918) quoted by } \\
\text { Marble and White (1920) }\end{array}$ & $\begin{array}{l}37 \\
21\end{array}$ & Syphilitic aorta & $\begin{array}{l}\text { Syphilis } \\
\text { Traumatic }\end{array}$ & War wound of chest \\
\hline 13 & $\begin{array}{l}\text { Sherman and Roman (1926) } \\
\text { quoted by d'Aunoy and von } \\
\text { Haam (1934) }\end{array}$ & $7 \frac{1}{2}$ & Patent foramen ovale & Congenital & \\
\hline 14 & $\begin{array}{l}\text { Costa (1929) quoted by } \\
\text { d'Aunoy and von Haam } \\
\text { (1934) }\end{array}$ & 44 & & , & \\
\hline $\begin{array}{l}15 \\
16\end{array}$ & $\begin{array}{l}\text { Barnes and Stedem (1933) .. } \\
\text { Wolf-Bremen (1936) quoted } \\
\text { by Deterling and Clagett } \\
\text { (1947) }\end{array}$ & $\begin{array}{l}50 \\
21\end{array}$ & & ? Mycotic & Died of rupture into pleural cavity \\
\hline 17 & Palmer and Kempf (1939) .. & 44 & $\begin{array}{l}\text { Patent ductus + subacute } \\
\text { bacterial endocarditis }\end{array}$ & Mycotic & Also aneurysm of trunk \\
\hline 18 & $\begin{array}{l}\text { Lelli (1941) quoted by Deter- } \\
\text { ling and Clagett (1947) }\end{array}$ & $?$ & , , , , , &, & \\
\hline 19 & $\begin{array}{l}\text { Hora and Wendt (1941) quoted } \\
\text { by Deterling and Clagett } \\
\text { (1947) }\end{array}$ & $?$ & & , & \\
\hline 20 & Thompson and Gersti (1946) & 27 & & $? \quad$, & $\begin{array}{l}\text { Anatomical site of origin of large aneurysm } \\
\text { in right chest not given }\end{array}$ \\
\hline 21 & Pirani et al. (1949) $\quad$. & 10 & & $\begin{array}{l}\text { Probably } \\
\text { mycotic }\end{array}$ & $\begin{array}{l}\text { No organisms found; peripheral venous } \\
\text { thromboses with multiple emboli }\end{array}$ \\
\hline 22 & Lillian (1949) & 17 & , & Mycotic & $\begin{array}{l}\text { Died of massive haemoptysis; also aneurysm } \\
\text { of P.A. trunk }\end{array}$ \\
\hline 23 & Mackenzie and Clagett (1953) & 26 & & Congenital & $\begin{array}{l}\text { P.A. pressure } 6010 \text { ? reason. Successful } \\
\text { lobectomy with removal of aneurysm }\end{array}$ \\
\hline 24 & Beasley et al. (1954) .. & 11 & & $\begin{array}{l}\text { ? Mycotic } \\
\text { ? Congenital }\end{array}$ & $\begin{array}{l}\text { Died after pneumonectomy. Aneurysm } \\
\text { appeared during illness suggestive of } \\
\text { septicaemia }\end{array}$ \\
\hline 25 & Konhaus and Kunkel (1955) & 57 & & Congenital & $\begin{array}{l}\text { Lobectomy performed for shadow picked up } \\
\text { on routine chest radiograph, thought to } \\
\text { be a tuberculoma }\end{array}$ \\
\hline 26 & Taber and Ehrenhaft (1956) & 5 & & Mycotic & $\begin{array}{l}\text { P.A. pressure } 110 \text { systolic-? cause. Staphy- } \\
\text { lococcal septicaemia before appearance of } \\
\text { aneurysms. Child died after lobectomy }\end{array}$ \\
\hline 27 & Sancetta et al. (1958) & 11 & & Congenital & $\begin{array}{l}\text { Murmur from babyhood which disappeared } \\
\text { after lobectomy. P.A. pressure } 9015- \\
\text { ? cause. Child had staphylococcal septi- } \\
\text { caemia. However, histology of aneurysm } \\
\text { considered by authors not to be in favour } \\
\text { of mycotic aetiology }\end{array}$ \\
\hline 28 & Kerwin and Jaffe (1959) & 34 & $\begin{array}{l}\text { Patent ductus + aneurysm of } \\
\text { the ductus }\end{array}$ & Mycotic & $\begin{array}{l}\text { Not bacterial; developed at site of lodge- } \\
\text { ment of suture material from attempt to } \\
\text { ligate ductus }\end{array}$ \\
\hline$\underset{30}{29}$ & Hughes and Stovin (1959) & $\begin{array}{l}35 \\
14\end{array}$ & & ? Mycotic & $\begin{array}{l}\text { Multiple peripheral venous thromboses with } \\
\text { pulmonary embolization, no evidence of } \\
\text { infection. Both died of massive haemopty- } \\
\text { sis }\end{array}$ \\
\hline 31 & Present case & 25 & Vegetation in $\mathbf{R}$. ventricle & Mycotic & Repeated septic embolization \\
\hline
\end{tabular}


the second hospital admission were compatible with the lodgment of septic emboli in the lung.

Of 31 reported cases of aneurysms of the large intrapulmonary arteries (see Table), including the patient reported here, 16 were mycotic and eight were congenital, with one each due to syphilis, trauma, and impaction of embolic suture material. In the remaining four cases a definite aetiology was not established, but it seems likely from the available evidence that they too were mycotic. Thus the patient of Thompson and Gerstl (1946) had had several episodes of pyrexia, chest pain, haemoptysis, and changing shadows on chest radiographs over a period of two years. Sulphonamides were used in the treatment of these attacks. The aneurysm developed about three months before death. At necropsy the wall of the aneurysm was composed of fibrous tissue with areas of small round cell infiltration, and there were many infarcts of different ages in the lungs. The authors suggested polyarteritis as a possible diagnosis. However, Ellman (1956) and Rose and Spencer (1957) do not report aneurysm formation in pulmonary arteries of this size in polyarteritis, and it seems probable that septic embolization, modified by sulphonamides, was responsible. Beasley, Chesterman, and Harvey (1954) observed the development of an aneurysm at the fork of the left pulmonary artery in their patient, aged 15 months, over a two-month period. The child was ill following measles with anaemia, splenomegaly, and indefinite shadows in the lung fields, and died after pneumonectomy. A full post-mortem examination was not obtained, and examination of the operation specimen did not establish the aetiology. However, it seems likely that this, too, was due to mycotic softening. Hughes and Stovin (1959) reported two cases in which the development of the pulmonary aneurysms was preceded by multiple venous thromboses, including intracranial thromboses. No direct evidence of infection was found. However, one patient developed aneurysms of the popliteal and carotid arteries which required surgery during the course of his illness, and at necropsy the appearance of the kidneys of the other was compatible with previous subacute bacterial endocarditis. Nevertheless, the authors favoured a diagnosis of aseptic pulmonary embolism with an associated degenerative condition of the vasa vasorum of the pulmonary arteries rather than septic embolization with mycotic softening.

In addition to weakness of the arterial wall, whether mycotic or congenital, many cases have evidence of an increased pressure within the lumen of the artery. In the three instances where cardiac catheterization was performed, pulmonary hypertension was demonstrated, though no cause for the raised pressure was found. In the seven cases of patent ductus arteriosus some increase in pressure seems likely, as in the two instances of septal defect, and an accentuated pulmonary second sound or an enlarged right ventricle at necropsy is occasionally reported. There was right-sided enlargement at necropsy in our own case, though there had been no clinical evidence of pulmonary hypertension; presumably the multiple embolization was responsible. We support the suggestion of D'Aunoy and von Haam (1934) that both factors are important in the pathogenesis.

A good case can be made for surgical removal of the aneurysm whenever feasible, as massive and often fatal haemoptysis occurred in several of the recorded cases. This has been advocated by Mackenzie and Clagett (1953) and was successful in their case and in those of Konhaus and Kunkei (1955) and Sancetta, Driscol, and Hackel (1958). Obviously the multiplicity of the lesions in the present case would have precluded surgery even if the diagnosis had been made in time.

A feature of the recorded cases is the youth of most of the patients. Aneurysms of the trunk and primary branches also occur at a younger age than aortic aneurysms (Deterling and Clagett, 1947). One factor contributing to this is probably the congenital lesions involved in the pathogenesis, whether congenital weakness of the wall of the artery or congenital heart lesions with superimposed subacute bacterial endocarditis.

\section{SUMMARY}

A case of multiple mycotic aneurysms of the secondary and tertiary branches of the pulmonary arteries is reported, and the pathogenesis is discussed. Only 30 cases of aneurysms of these vessels have been discovered in the available literature, and these are briefly reviewed. In the majority of instances the aneurysms were mycotic, most of the remainder having been ascribed to congenital weakness. An additional aetiological factor in some cases has been a raised pulmonary arterial pressure.

We should like to thank the Medical Superintendent of the Johannesburg Hospital, Dr. K. F. Mills, and Professor J. H. Gear and Mr. L. Fatti for permission to publish this case report. Particular thanks are due to Dr. J. B. Barlow and Dr. R. E. Yodaiken for much helpful advice and criticism, and to Mr. B. Treurnich for the histological preparations. 


\section{REFERENCES}

Bain, R. C. Edwards, J. E., Scheifley, C. H., and Geraci, J. E. (1958). Amer. J. Med., $24,98$.

Barker, P. S. (1949). Amer. Heart J., 37, 1054.

Barnes, J. M., and Stedem, D. E. (1933). Amer. J. Roentgenol., 30, 443.

Beasley, D. M. G., Chesterman, J. T., and Harvey, C. C. (1954). Arch. Dis. Childh., 29, 346.

Beattie, J. M., and Hall, A. J. (1912). Proc. roy. Soc. Med., 5, Path. Sect., p. 147.

Blades, B., Ford, W., and Clark, P. (1950). Circulation, 2, 565.

Blumgart, H. L. (1933). Med. Clin. N. Amer., 16, 881.

Boyd, L. J., and McGavack, T. H. (1939). Amer. Heart J., 18, 562.

Campbell, M. (1957). Lancet, 1, 111

Churton, T. (1897). Brit. med. J., 1, 1223.

Clifford, W. J., MacGillivray, W. F., and Goodale, R. H. (1950). Amer. J. Roentgenol., 64, 414.

Contro, S., Miller, R. A., White, H., and Potts, W. J. (1958). Circulation, 17, 424.

D'Aunoy, R., and Haam, E. von (1934). J. Path. Bact., 38, 39.

Deterling, R. A., Jr., and Clagett, O. T. (1947). Amer. Heart J., 34, 471.

Dotter, C. T., and Steinberg, I. (1949). New Engl. J. Med., 240, 51.

Ellman, P. (1956). Postgrad. med. J., 32, 370.

Fisher, A. M., Wagner, H. N., Jr., and Ross, R. S. (1955). A.M.A. Arch. intern. Med., 95, 427.

Franklin, R., and Ritchie, A. C. P. (1956). Brit. med. J., $2,983$.

Grelland, R. (1950). Acta med. scand., 137, 374.

Hay, D. R. (1960). Quart. J. Med., 29, 313.

Hughes, J. P., and Stovin, P. G. (1959). Brit. J. Tuberc., 53, 19.
Humphry, L. (1912). J. Path. Bact., 17, 212.

Israels, M. G. (1951). Canad. med. Ass. J., 64, 433.

Jelinek, J. E., and Owen, T. K. (1958). Brit. med. J., 1, $81 \mathrm{~s}$

Kerwin, A. J., and Jaffe, F. A. (1959). Amer. J. Cardiol., 3, 397.

Konhaus, C. H., and Kunkel, P. A., Jr. (1955). Ann. Surg., 142, 997.

Krzyszkowski, J. (1902). Wien. klin. Wschr., 15, 92.

Lillian, M. (1949). Amer. J. Med., 7, 280.

Lindert, M. C. F., and Correll, H. L. (1950). J. Amer. med. Ass., $143,888$.

Mackenzie, D. A., and Clagett, O. T. (1953). J. thorac. Surg., 25, 524.

Marble, H. C., and White, P. D. (1920). J. Amer. med. Ass., 74, 1778.

Newton, E. J. (1956). Quart. J. Med., 25, 201.

Palner, H. D., and Kempf, M. (1939). J. Amer. med. Ass., 113, 1788.

Pirani, C. L., Ewart, F. E., Jr., and Wilson, A. L. (1949). Amer. J. Dis. Child., 77, 460.

Priviteri, C. A., and Gay, B. B., Jr. (1950). Radiology, 55, 247.

Reid, J. M., and Stevenson, J. G. (1959). Dis. Chest, 36, 104.

Rose, G. A., and Spencer, H. (1957). Quart. J. Med., 26, 43.

Sancetta, S. M., Driscol, T., and Hackel, D. B. (1958). Amer. Heart J., 55, 607.

Smith, G. (1959). Brit. J. Surg., 46, 373.

Taber, R. E., and Ehrenhaft, J. L. (1956). A.M.A. Arch. Surg., 73, 567.

Thompson, H. (1877). Med. Tms Gaz. (Lond.), 2, 56.

Thompson, S. A., and Gerstl, B. (1946). Arch. intern. Med., 95, 427.

Trevor, R. S. (1912). Proc. roy. Soc. Med., 5, Path. Sect., p. 155.

Tulloch, L. G., Alder, V. G., and Gillespie, W. A. (1960). Brit. med. J., 2, 354.

Verloop, M. C. (1948). Acta Anat. (Basel), 5, 171.

Warthin, A. S. (1917). Amer. J. Syph., 1, 693.

Wright, H. D. (1927). J. Path. Bact., 30, 185.

Zaky, H. A. (1952). Dis. Chest, 21, 194. 